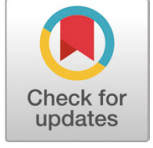

Received: Jul 17, 2020

Revised: Jul 30, 2020

Accepted: Aug 8, 2020

\#These authors contributed equally to this work.

${ }^{*}$ Corresponding author

Jin Ho Cho

Division of Food and Animal Science,

Chungbuk National University,

Cheongju 28644, Korea.

Tel: +82-43-261-2544

E-mail: jinhcho@chungbuk.ac.kr

Hyeun Bum Kim

Department of Animal Resource and

Science, Dankook University,

Cheonan 31116, Korea.

Tel: +82-41-550-3653

E-mail: hbkim@dankook.ac.kr

Copyright $\odot 2020$ Korean Society of Animal Sciences and Technology.

This is an Open Access article distributed under the terms of the Creative Commons Attribution Non-Commercial License (http:// creativecommons.org/licenses/by$\mathrm{nc} / 4.0 /$ ) which permits unrestricted non-commercial use, distribution, and reproduction in any medium, provided the original work is properly cited.

ORCID

Yong Ju Kim

https://orcid.org/0000-0002-0960-0884

Tae Heon Kim

https://orcid.org/0000-0001-9054-5781

\section{Effects of different levels of crude protein and protease on nitrogen utilization, nutrient digestibility, and growth performance in growing pigs}

\author{
Yong Ju Kim ${ }^{1 \#}$, Tae Heon Kim ${ }^{1 \#}$, Min Ho Song ${ }^{2 \#}$, Ji Seon An ${ }^{1 \#}$, Won Yun ${ }^{1}$, \\ Ji Hwan Lee ${ }^{1}$, Han Jin Oh ${ }^{1}$, Jun Soeng Lee ${ }^{1}$, Gok Mi Kim ${ }^{3}$, Hyeun Bum Kim ${ }^{4 *}$ \\ and Jin $\mathrm{Ho} \mathrm{Cho}^{1 *}$ \\ ${ }^{1}$ Division of Food and Animal Science, Chungbuk National University, Cheongju 28644, Korea \\ ${ }^{2}$ Department of Animal Science and Biotechnology, Chungnam National University, Daejeon 34134, Korea \\ ${ }^{3}$ Department of Beauty Art, Yonam College, Cheonan 31005, Korea \\ ${ }^{4}$ Department of Animal Resource and Science, Dankook University, Cheonan 31116, Korea
}

\section{Abstract}

This study was conducted to evaluate the effects of different levels of crude protein (CP) and protease on nitrogen $(\mathrm{N})$ utilization, nutrient digestibility, and growth performance in growing pigs. A total of six crossbred ([Landrace $\times$ Yorkshire] $\times$ Duroc) barrows were individually accepted in $1.2 \mathrm{~m} \times 0.7 \mathrm{~m} \times 0.96 \mathrm{~m}$ stainless steel metabolism cages. The pigs (average initial body weight of $27.91 \pm 1.84 \mathrm{~kg}$ ) randomly assigned to six diets with six weeks $(6 \times 6$ Latin square design). The experiment was carried out in an environment with a temperature of 23 $\pm 1.5^{\circ} \mathrm{C}$, a relative humidity of $83 \pm 2.3 \%$ and a wind speed of $0.25 \pm 0.03 \mathrm{~m} / \mathrm{s}$. The dietary treatments were arranged in a $2 \times 3$ factorial design with two levels of CP $(15.3 \%$ or $17.1 \%)$ and three levels of protease $(0 \mathrm{ppm}, 150 \mathrm{ppm}$, or $300 \mathrm{ppm})$. The average daily gain and gain to feed ratio $(\mathrm{G}: \mathrm{F})$ tended to increase $(p=0.074)$ with increasing amounts of protease. The low CP level diet reduced $(p<0.050)$ urinary and fecal $\mathrm{N}$ concentrations, the total $\mathrm{N}$ excretion in feces, and increased $(p<0.050) \mathrm{N}$ retention. Different protease levels in the diet did not affect $(p>0.05)$ at $\mathrm{N}$ intake, but supplementation of the diets with $300 \mathrm{ppm}$ protease decreased $(p<0.050)$ the $N$ concentration in urine and feces and tended to increase $(p=0.061)$ the percentage of $\mathrm{N}$ retention retained of the total $\mathrm{N}$ intake. The dietary $\mathrm{CP}$ level did not affect $(p>0.050)$ the apparent total tract digestibility (ATTD) of dry matter, digestible energy (DE), and metabolic energy (ME), but diet supplementation with $300 \mathrm{ppm}$ protease showed higher ( $p$ $<0.050)$ ATTD of DE and ME than in the protease-free diet. Therefore, a low protein diet with protease could improve the utilization of nitrogen, thereby reducing the negative effect of $\mathrm{N}$ excretion into the environment while maintaining or increasing growth performance compared to a high protein diet.

Keywords: Protein, Protease, Nitrogen, Digestibility, Growing pigs 
Min Ho Song

https://orcid.org/0000-0002-4515-5212

Ji Seon An

https://orcid.org/0000-0002-9205-8095

Won Yun

https://orcid.org/0000-0002-1835-2640

Ji Hwan Lee

https://orcid.org/0000-0001-8161-4853

Han Jin Oh

https://orcid.org/0000-0002-3396-483X

Jun Soeng Lee

https://orcid.org/0000-0002-2497-6855

Gok Mi Kim

https://orcid.org/0000-0003-1053-4535

Hyeun Bum Kim

https://orcid.org/0000-0003-1366-6090

Jin Ho Cho

https://orcid.org/0000-0001-7151-0778

Competing interests

No potential conflict of interest relevant to

this article was reported.

Funding sources

The present research was supported by

Eugene-Bio in 2020

Acknowledgements

Not applicable.

Availability of data and material

Upon reasonable request, the datasets

of this study can be available from the

corresponding author.

Authors' contributions

Conceptualization: Kim YJ, Kim TH, Song MH, An JS.

Data curation: Kim YJ.

Formal analysis: Kim YJ, An JS.

Investigation: Kim TH, Yun W, Lee $\mathrm{JH}, \mathrm{Oh} \mathrm{HJ}$, Lee JS, Kim GM.

Writing - original draft: Kim YJ, Kim TH.

Writing - review \& editing: Kim HB, Cho JH.

Ethics approval and consent to participate The experimental protocol was approved and conducted under the guidelines of the Animal Care and Use Committee of Chungbuk National University (CBNUA-1428-20-02)

\section{INTRODUCTION}

The concentration of dietary crude protein $(\mathrm{CP})$ has been closely related to growth performance. However, undigested $\mathrm{CP}$ in pig diets causes environmental pollution and odor. A prior study reported that when the dietary protein content increased above a certain level, undigested protein increased, resulting in increased intestinal pathogenic microorganisms (Escherichia coli, Clostridium, and Enterobacteriaceae) and decreased numbers of beneficial Lactobacillus bacteria [1]. According to the US Environmental Protection Agency (US EPA, 2004), ammonia released during animal production constituted about $50 \%$ of the total anthropogenic ammonia emissions, causing eutrophication, soil acidification, and impaired visibility [2]. Pigs fed a high CP diet had higher urinary energy excretion and reduced on energy retention and the efficiency [3].

Many researchers have reported that lower $\mathrm{CP}$ with added crystalline amino acids-maintained growth performance and reduced nitrogen excretion in growing to finishing pigs [4-6]. The addition of crystalline amino acids to $12 \% \mathrm{CP}$ diets for growing pig showed equal performance, and reduced nitrogen $(\mathrm{N})$ emissions and cost compared to pigs fed a $16 \% \mathrm{CP}$ diet $[7,8]$.

Protease has been used in swine diets as part of enzyme cocktails [9]. Various studies have shown that dietary supplementation with protease had positive effects on nutrient digestibility and growth performance in weaning and growing pigs [9-14]. Also, protease has been available commercially and shown beneficial effects on nutrient digestibility and the growth performance of pigs [9,15-18].

Lower $\mathrm{CP}$ diets with protease supplementation are expected to show positive effects on the growth performance, nitrogen emission, and energy metabolism of pigs. However, it is not known how much protease supplementation is appropriate in low $\mathrm{CP}$ diets. Therefore, the main purpose of this experiment was to evaluate the effects of different levels of $\mathrm{CP}$ and protease on nitrogen utilization, nutrient digestibility, and growth performance in growing pigs.

\section{MATERIALS AND METHODS}

\section{Experiment design and housing}

The experimental protocol was approved by the Institutional Animal Care and Use Committee of Chungbuk National University, Cheongju, Korea (CBNUA-1428-20-02).

A total of six crossbred ([Landrace $\times$ Yorkshire $] \times$ Duroc) barrows were individually accepted in $1.2 \mathrm{~m} \times 0.7 \mathrm{~m} \times 0.96 \mathrm{~m}$ stainless steel metabolism cages. The pigs (average initial body weight of $27.91 \pm 1.84 \mathrm{~kg})$ randomly assigned to six diets with six weeks $(6 \times 6$ Latin square design). The experiment was carried out in an environment with a temperature of $23 \pm 1.5^{\circ} \mathrm{C}$, a relative humidity of $83 \pm 2.3 \%$ and a wind speed of $0.25 \pm 0.03 \mathrm{~m} / \mathrm{s}$.

\section{Diets and feeding}

The diets were adapted to exceed or meet the NRC [19] nutritional requirements for pigs. Table 1 shows the nutritional content of the main ingredients used in this experiment. The dietary treatments were arranged in a $2 \times 3$ factorial design with two levels of $\mathrm{CP}(15.3 \%$ or $17.1 \%)$ and three levels of protease ( $0 \mathrm{ppm}, 150 \mathrm{ppm}$, or $300 \mathrm{ppm})$. The PT125TM a protease enzyme was supported by a commercial company (Eugene-Bio, Suwon, Korea). According to the supplier, protease PT125TM, an alkaline serine endopeptidase produced by a fermentation process by a Streptomyces bacterial strain at optimal $\mathrm{pH} 8.5$, was purified from a crude solution produced by a Streptomyces spp. optimized to produce only proteases. The experiment was conducted for six weeks. The daily feed allowance was arranged to 2.7 times the requirement to maintain digestible energy (DE, $2.7 \times$ $110 \mathrm{kcal}$ of $\mathrm{DE} / \mathrm{kg} \mathrm{BW}{ }^{0.75}$ ) [19]. The daily diet was distributed in half and fed at 8:00 and 17:00 h. 
Table 1. Chemical composition of the basal diets (as-fed basis)

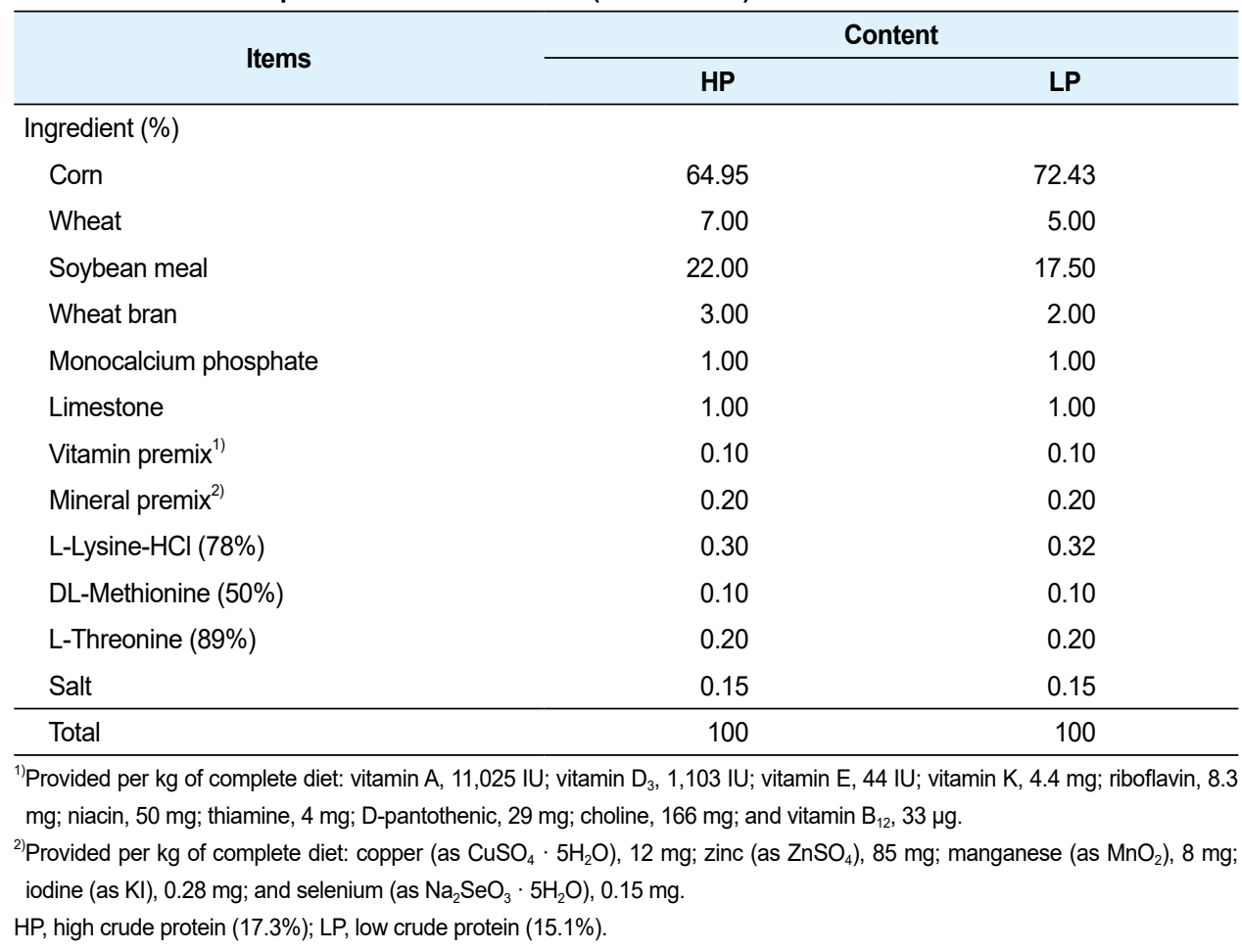

Feed was always mixed with water in a 1 to 1 ration. During the experiment, pigs were freely supplied with water.

\section{Sampling and analysis}

Beginning of each week pigs were weighed individually, and daily feed supply and residual feed quantity were recorded. Each week, the experiment consisted of 4 days of adaptation period and 3 days of collection period to collect urine and feces. The total feces were immediately packaged in plastic bags when they were produced in the metabolism cages, and stored at $-20^{\circ} \mathrm{C}$ during experiment period. Urine was collected once a day on to buckets that filled with $50 \mathrm{~mL}$ of $6 \mathrm{~mol} / \mathrm{L} \mathrm{HCl}$ that under the metabolic cages. The total collected urine was weighed and stored at $-20^{\circ} \mathrm{C}$. Feces and urine collection were performed according to the method described in Song et al. [20]. The fecal sample was dried in a forced-air oven and then crushed on a 1-mm screen and thoroughly melded before sub-sample collection for chemical analysis. The gross energy of urine, feces and diet was analyzed by an adiabatic oxygen bomb calorimeter (Par Instruments, Moline, Il, USA). The nitrogen content in feces and urine was also analyzed [21]. The calculations of DE and metabolizable energy were conducted in the manner described by Lammers et al. [22].

\section{Calculations}

$\mathrm{DE}$ was calculated by subtracting the GE in the feces from the dietary GE. The DE calculated from dietary chemical composition (Eq. 1). The metabolic energy (ME) was calculated directly from the nutritional composition and the DE (Eq. 2).

$$
\begin{aligned}
& \mathrm{DE}=1,161+(0.749 \times \mathrm{GE})-(4.3 \times \mathrm{Ash})-(4.1 \times \mathrm{NDF}) \\
& \mathrm{ME}=(1.00 \times \mathrm{DE})-(0.68 \times \mathrm{CP})
\end{aligned}
$$




\section{Statistical analysis}

The data for the effects of different level of dietary $\mathrm{CP}$ with different level of protease supplementation on the apparent total tract digestibility (ATTD) of nitrogen, energy and growth performance in growing pigs were subjected to two-way ANOVA, with addition levels, types and their interactions as main effects and litter as covariate. The data were statistically analyzed by the generalized linear moder (GLM) procedure in IBM SPSS statistics v.25 (SPSS, Chicago, IL, USA). Each cage was used for each experimental unit. Differences between treatment groups was determined using Tukey's honest significant difference (HSD) test with a $p$-value of $<0.05$ indicating significance.

\section{RESULT}

\section{Growth performance}

The growth performance data are shown in Table 2. Average daily gain (ADG) and gain to feed ratio $(\mathrm{G}: \mathrm{F})$ tended to increase $(p=0.074)$ with increasing dietary protease supplementation, but the dietary CP levels did not affect $(p>0.050)$ pig performance.

\section{Nitrogen utilization}

The $\mathrm{N}$ utilization data are shown in Table 3. The low CP level diet reduced $(p<0.050)$ the urine and fecal $\mathrm{N}$ concentration, fecal $\mathrm{N}$ excretion, and total $\mathrm{N}$ excretion, and increased $(p<0.050) \mathrm{N}$ retention. Diet supplementation with protease did not affect $\mathrm{N}$ intake but decreased $(p<0.050)$ urine and fecal $\mathrm{N}$ concentration and tended to increase $(p=0.061)$ the proportion of $\mathrm{N}$ retained from the total $\mathrm{N}$ intake. However, there was no significant difference $(p>0.050)$ in nitrogen utilization in the interaction of $\mathrm{CP}$ and protease levels in the diets. Also, the biological values were not affected by the effects of $\mathrm{CP}$, protease levels, and their interaction.

\section{Nutrient digestibility}

The apparent ATTD of the nutrients is shown in Table 4. The CP level in the diet did not affect $(p$ $>0.050)$ the ATTD of DM, DE, and ME. Supplementation with $300 \mathrm{ppm}$ protease showed higher $(p<0.050) \mathrm{DE}$ and ME than the protease-free diet.

\section{DISCUSSION}

The need to reduce $\mathrm{N}$ excretion has become a very important topic in the pig industry. Urinary and fecal $\mathrm{N}$ excretion occupy the largest proportion of $\mathrm{N}$ excretion in the animal industry. Pfeiffer et al. [24] reported strong correlation was observed between an increase in CP intake and an increase in $\mathrm{N}$ content in the urine also excessive protein supply as well as excess amino acid is a source of large amounts of excreted urea and is responsible for low nitrogen absorption coefficient. $\mathrm{N}$ content in feces was also reported to be lower in low protein diets than in high protein diets. Consuming a low

Table 2. Effects of dietary crude protein level with protease supplementation on growth performance in growing pigs

\begin{tabular}{|c|c|c|c|c|c|c|c|c|c|c|}
\hline \multirow{2}{*}{ Item } & \multicolumn{3}{|c|}{ HP } & \multicolumn{3}{|c|}{ LP } & \multirow{2}{*}{ SE } & \multicolumn{3}{|c|}{$p$-value } \\
\hline & PT 0 & PT 150 & PT 300 & PT 0 & PT 150 & PT 300 & & $\mathrm{CP}$ & Protease & $\mathrm{CP} \times$ protease \\
\hline$A D G(g / d)$ & 511 & 523 & 555 & 495 & 526 & 576 & 12 & 0.958 & 0.068 & 0.645 \\
\hline $\operatorname{ADFI}(g / d)$ & 1,350 & 1,415 & 1,394 & 1,374 & 1,380 & 1,386 & 44 & 0.949 & 0.950 & 0.969 \\
\hline G:F & 0.361 & 0.370 & 0.386 & 0.352 & 0.375 & 0.405 & 0.010 & 0.863 & 0.074 & 0.468 \\
\hline
\end{tabular}

Each value is the mean value of 6 replicates (1 pig/cage; $6 \times 6$ latin square).

HP, high crude protein (17.3\%); LP, low crude protein (15.1\%); CP, crude protein; PT, protease (ppm); ADG, average daily gain; ADFI, average daily feed intake; G:F, feed efficiency. 
Table 3. Effect of dietary crude protein level and supplementation protease on nitrogen utilization in growing pigs

\begin{tabular}{|c|c|c|c|c|c|c|c|c|c|c|}
\hline \multirow{2}{*}{ Items } & \multicolumn{3}{|c|}{ HP } & \multicolumn{3}{|c|}{ LP } & \multirow{2}{*}{ SE } & \multicolumn{3}{|c|}{$p$-value } \\
\hline & PT 0 & PT 150 & PT 300 & PT 0 & PT 150 & PT 300 & & $\mathrm{CP}$ & Protease & $\mathrm{CP} \times$ protease \\
\hline$N$ intake $(g / d)$ & 39.77 & 39.65 & 39.53 & 35.16 & 35.03 & 34.69 & 0.54 & $<.001$ & 0.934 & 0.992 \\
\hline Urine excretion (kg/d) & 2.01 & 1.99 & 1.98 & 2.07 & 2.03 & 1.94 & 0.11 & 0.928 & 0.965 & 0.986 \\
\hline $\mathrm{N}$ concentration in urine $(\%)$ & $0.157^{\mathrm{a}}$ & $0.142^{\mathrm{ab}}$ & $0.130^{b}$ & $0.135^{\mathrm{a}}$ & $0.120^{\mathrm{ab}}$ & $0.115^{b}$ & 0.004 & 0.010 & 0.034 & 0.905 \\
\hline$N$ excretion in urine $(\mathrm{g} / \mathrm{d})$ & 3.18 & 2.79 & 2.54 & 2.72 & 2.46 & 2.22 & 0.17 & 0.308 & 0.434 & 0.983 \\
\hline Feces excretion (g/d) & 253 & 251 & 258 & 258 & 262 & 255 & 2 & 0.570 & 0.983 & 0.689 \\
\hline $\mathrm{N}$ concentration in feces (\%) & $3.73^{\mathrm{a}}$ & $3.66^{\mathrm{a}}$ & $3.46^{\mathrm{b}}$ & $3.14^{\mathrm{a}}$ & $3.08^{\mathrm{a}}$ & $2.94^{\mathrm{b}}$ & 0.05 & $<.001$ & $<.001$ & 0.649 \\
\hline$N$ excretion in feces $(\mathrm{g} / \mathrm{d})$ & 9.46 & 9.21 & 8.93 & 8.07 & 8.05 & 7.51 & 0.15 & $<.001$ & 0.106 & 0.858 \\
\hline Total N excretion (g/d) & 12.63 & 12.00 & 11.46 & 10.79 & 10.52 & 9.73 & 0.24 & $<.001$ & 0.082 & 0.929 \\
\hline$N$ retention $(\mathrm{g} / \mathrm{d})$ & 27.14 & 27.65 & 28.07 & 24.38 & 24.52 & 24.96 & 0.42 & $<.001$ & 0.689 & 0.971 \\
\hline $\mathrm{N}$ retention ( $\%$ of $\mathrm{N}$ intake) & 68.15 & 69.83 & 70.98 & 69.24 & 69.89 & 71.98 & 0.47 & 0.441 & 0.061 & 0.881 \\
\hline Biological value $(\%)^{1)}$ & 89.44 & 91.01 & 91.67 & 90.12 & 90.88 & 91.86 & 0.53 & 0.827 & 0.355 & 0.956 \\
\hline
\end{tabular}

Each value is the mean value of 6 replicates ( 1 pig/cage; $6 \times 6$ latin square).

${ }^{a, b}$ Means in the same row with different superscripts differ $(p<0.05)$.

${ }^{1)}(\mathrm{N}$ intake - urinary $\mathrm{N}$ excretion - fecal $\mathrm{N}$ excretion) / ( $\mathrm{N}$ intake - fecal $\mathrm{N}$ excretion $) \times 100$.

HP, high crude protein (17.3\%); LP, low crude protein (15.1\%); CP, crude protein; PT, protease (ppm); N, nitrogen.

Table 4. Effects of dietary crude protein level and protease supplementation on the apparent total tract digestibility of nutrients in growing pigs

\begin{tabular}{|c|c|c|c|c|c|c|c|c|c|c|}
\hline \multirow{2}{*}{ Items } & \multicolumn{3}{|c|}{ HP } & \multicolumn{3}{|c|}{ LP } & \multirow{2}{*}{ SE } & \multicolumn{3}{|c|}{$p$-value } \\
\hline & PT 0 & PT 150 & PT 300 & PT 0 & PT 150 & PT 300 & & $\mathrm{CP}$ & Protease & $\mathrm{CP}^{*} \times$ protease \\
\hline Dry matter & 81.81 & 82.10 & 81.29 & 81.44 & 81.03 & 81.51 & 0.22 & 0.386 & 0.919 & 0.536 \\
\hline Digestible energy & $72.90^{\mathrm{a}}$ & $74.47^{\mathrm{ab}}$ & $75.97^{b}$ & $74.08^{\mathrm{a}}$ & $74.40^{\mathrm{ab}}$ & $76.21^{\mathrm{b}}$ & 0.35 & 0.485 & 0.008 & 0.708 \\
\hline Metabolic energy & $71.52^{\mathrm{a}}$ & $73.46^{\mathrm{ab}}$ & $74.93^{\mathrm{b}}$ & $72.60^{\mathrm{a}}$ & $73.23^{\mathrm{ab}}$ & $75.09^{b}$ & 0.34 & 0.549 & 0.001 & 0.625 \\
\hline
\end{tabular}

Each value is the mean value of 6 replicates ( 1 pig/cage; $6 \times 6$ latin square).

a,b Means in the same row with different superscripts differ $(p<0.05)$.

$\mathrm{HP}$, high crude protein (17.3\%); LP, low crude protein (15.1\%); PT, protease (ppm); CP, crude protein.

$\mathrm{CP}$ diet could reduce $\mathrm{N}$ excretion [25]. However, an adequate amount of $\mathrm{CP}$ for pig growth is essential. Therefore, it is important to have the optimal effect with a small amount of CP. It is a common strategy to use protein enzymes in pig diets to increase the efficiency of $\mathrm{N}$ utilization [26]. The method of stimulating the digestion of nutrients including nitrogen through dietary supplementation of exogenous enzymes has attracted the attention of the pig industry [14]. In several studies, protease has been shown to have positive effects on the nutrient digestibility or growth performance in pigs from weaning through finishing $[9,11,15,18,27]$. However, there are still something to be defined about protease in diets $[13,16]$. The effectiveness of supplying protease enzyme in pig diets can differ due to disparity between the ingredients, the age of the pigs, or enzyme products [13]. Therefore, this experiment was performed to investigate the effects of different levels of $\mathrm{CP}$ and protease on nitrogen utilization, nutrient digestibility, and growth performance in growing pigs.

In this study, G:F and ADG tended to increase $(p=0.074)$ with increasing dietary protease supplementation, but the level of dietary protein was not significant difference $(p<0.050)$ on pig performance. This observation corresponds with results reported by Omogbenigun et al. [12], who observed the effect of exogenous enzymes on pig ADG. This result might be due to the better digestibility of nutrients in protease-supplemented diets compared to basal diets. Table 4 shows that $\mathrm{DE}$ and ME were significantly higher $(p<0.050)$ at low CP levels with $300 \mathrm{ppm}$ protease supplementation compared to the other treatments. 
Many studies have demonstrated a correlation between protein and nitrogen emission. The use of relatively insufficient $\mathrm{CP}$ in growing pigs can cause an accumulation of organic compounds and manure that emits ammonia and odors [28]. The protease was expected to increase the digestibility of the protein by cleaving the peptide bond in the protein by hydrolysis to break down the protein into small polypeptides or single amino acids. Table 3 shows that the low CP diet decreased $(p<$ 0.050 ) urinary and fecal $\mathrm{N}$ concentrations, fecal $\mathrm{N}$ excretion, and total $\mathrm{N}$ excretion. These results agreed with those of Dourmad and Henry [29] and Canh et al. [30], who reported a 10\% reduction in nitrogen excretion per point $\mathrm{CP}$ reduction in the diet, seen as a change from $12.63 \mathrm{~g} / \mathrm{d}$ to 10.52 $\mathrm{g} / \mathrm{d}$ from a $2 \%$ reduction in $\mathrm{CP}$ content. The low $\mathrm{CP}$ diet showed a decrease $(p<0.050)$ in nitrogen retention $(\mathrm{g} / \mathrm{d})$ compared to the high $\mathrm{CP}$ diet. However, there was no significant difference $(p>$ $0.050)$ in the percentage of nitrogen retained of the total $\mathrm{N}$ intake according to the dietary $\mathrm{CP}$ level. Nitrogen retention is the most important factor in reducing nitrogen excretion as much as possible while maintaining pig growth performance [31]. $\mathrm{N}$ retention and the percentage of $\mathrm{N}$ intake was not significantly different but tended to increase $(p=0.061)$ with increasing dietary protease supplementation. Also, protease supplementation reduced $(p<0.050)$ urinary and fecal $\mathrm{N}$ concentrations compared to those in the protease-free diet. $\mathrm{N}$ concentration in urine tended to decrease as the amount of protease addition increased. The fecal $\mathrm{N}$ concentration was not significantly different between the basal diet and the $150 \mathrm{ppm}$ protease-supplemented diet, but there was a significant difference in the $300 \mathrm{ppm}$ protease-supplemented diet.

Table 4 shows that the CP level did not affect $(p>0.050)$ nutrient digestibility. However, protease supplementation showed higher $(p<0.050) \mathrm{DE}$ and ME compared to the basal diet. In this experiment, both $\mathrm{DE}$ and $\mathrm{ME}$ increased as the amount of added protease increased. Protease is now known as dietary enzyme that target tight protein binding to increase protein availability. In our experiment, protease supplementation on diets show positive effect on DE and ME during the experimental period but made no difference on ADG and G:F. It has been suggested that endogenous protease enzymes can improve the digestibility of starch and protein, but have no effect on growth performance in pigs [32]. Dietary protease significantly improved the apparent ileal digestibility (AID) of CP not only corn but sorghum-based diets [33]. Furthermore, corn-based diets with protease increased the AID of $\mathrm{CP}$ and amino acids in growing pigs [34]. The protease enzyme appears to be due to improved protein digestibility on in the corn-soybean meal diets by progressing deoxidation two sulfurs through hydrolysis to break the cystine disulfide bond in soy proteins such as glycinin and $\beta$-conglycinin [35].

\section{CONCLUSION}

The results of this experiment showed that a low CP (15.1\%) diet with added protease (300 ppm) significantly lowered nitrogen emissions and increased energy utilization.

\section{REFERENCES}

1. Rist VTS, Weiss E, Sauer N, Mosenthin R, Eklund M. Effect of dietary protein supply originating from soybean meal or casein on the intestinal microbiota of piglets. Anaerobe. 2014;25:72-9. https://doi.org/10.1016/j.anaerobe.2013.10.003

2. Lee C, Hristov AN, Heyler KS, Cassidy TW, Lapierre H, Varga GA, et al. Effects of metabolizable protein supply and amino acid supplementation on nitrogen utilization, milk production, and ammonia emissions from manure in dairy cows. J Dairy Sci. 2012;95:5253-68. https://doi. org/10.3168/jds.2012-5366 
3. Holmes CW, Carr JR, Pearson G. Some aspects of the energy and nitrogen metabolism of boars, gilts and barrows given diets containing different concentrations of protein. Anim Sci. 1980;31:279-89. https://doi.org/10.1017/S0003356100024612

4. Kerr BJ, Easter RA. Effect of feeding reduced protein, amino acid-supplemented diets on nitrogen and energy balance in grower pigs. J Anim Sci. 1995;73:3000-8. https://doi. org/10.2527/1995.73103000x

5. Kerr BJ, McKeith FK, Easter RA. Effect on performance and carcass characteristics of nursery to finisher pigs fed reduced crude protein, amino acid-supplemented diets. J Anim Sci. 1995;73:433-40. https://doi.org/10.2527/1995.732433x

6. Deng D, Huang RL, Li TJ, Wu GY, Xie MY, Tang ZR, et al. Nitrogen balance in barrows fed low-protein diets supplemented with essential amino acids. Livest Sci. 2007;109:220-3. https:// doi.org/10.1016/j.livsci.2007.01.122

7. Hansen JA, Knabe DA, Burgoon KG. Amino acid supplementation of low-protein sorghum-soybean meal diets for 20-to 50-kilogram swine. J Anim Sci. 1993;71:442-51. https:// doi.org/10.2527/1993.712442x

8. Galassi G, Colombini S, Malagutti L, Crovetto GM, Rapetti L. Effects of high fibre and low protein diets on performance, digestibility, nitrogen excretion and ammonia emission in the heavy pig. Anim Feed Sci Technol. 2010;161:140-8. https://doi.org/10.1016/j.anifeedsci.2010.08.009

9. Zuo J, Ling B, Long L, Li T, Lahaye L, Yang C, et al. Effect of dietary supplementation with protease on growth performance, nutrient digestibility, intestinal morphology, digestive enzymes and gene expression of weaned piglets. Anim Nutr. 2015;1:276-82. https://doi. org/10.1016/j.aninu.2015.10.003

10. Yin YL, Baidoo SK, Jin LZ, Liu YG, Schulze H, Simmins PH. The effect of different carbohydrase and protease supplementation on apparent (ileal and overall) digestibility of nutrients of five hulless barley varieties in young pigs. Livest Prod Sci. 2001;71:109-20. https://doi. org/10.1016/S0301-6226(01)00215-9

11. Yin YL, Deng ZY, Huang HL, Li TJ, Zhong HY. The effect of arabinoxylanase and protease supplementation on nutritional value of diets containing wheat bran or rice bran in growing pig. J Anim Feed Sci. 2004;13:445-61. https://doi.org/10.22358/jafs/67611/2004

12. Omogbenigun FO, Nyachoti CM, Slominski BA. Dietary supplementation with multienzyme preparations improves nutrient utilization and growth performance in weaned pigs. J Anim Sci. 2004;82:1053-61. https://doi.org/10.2527/2004.8241053x

13. Ji F, Casper DP, Brown PK, Spangler DA, Haydon KD, Pettigrew JE. Effects of dietary supplementation of an enzyme blend on the ileal and fecal digestibility of nutrients in growing pigs.J Anim Science. 2008;86:1533-43. https://doi.org/10.2527/jas.2007-0262

14. Jo JK, Ingale SL, Kim JS, Kim YW, Kim KH, Lohakare JD, et al. Effects of exogenous enzyme supplementation to corn-and soybean meal-based or complex diets on growth performance, nutrient digestibility, and blood metabolites in growing pigs. J Anim Sci. 2012;90:3041-8. https://doi.org/10.2527/jas.2010-3430

15. O'Doherty JV, Forde S. The effect of protease and $\alpha$-galactosidase supplementation on the nutritive value of peas for growing and finishing pigs. Ir J Agric Food Res. 1999;38:217-26.

16. Adeola $\mathrm{O}$, Cowieson AJ. Board-invited review: opportunities and challenges in using exogenous enzymes to improve nonruminant animal production. J Anim Sci. 2011;89:3189-218. https://doi.org/10.2527/jas.2010-3715

17. Guggenbuhl P, Waché $Y$, Wilson JW. Effects of dietary supplementation with a protease on the apparent ileal digestibility of the weaned piglet.J Anim Sci.2012;90 suppl_4:152-4. https:// 
doi.org/10.2527/jas.53835

18. Mc Alpine PO, O'shea CJ, Varley PF, O'Doherty JV. The effect of protease and xylanase enzymes on growth performance and nutrient digestibility in finisher pigs. J Anim Sci. 2012;90 suppl_4:375-7.https://doi.org/10.2527/jas.53979

19. NRC [National Research Council]. Nutrient requirements of swine. 10th ed. Washington, DC: The National Academies Press; 1998.

20. Song GL, Li DF, Piao XS, Chi F, Yang WJ. Apparent ileal digestibility of amino acids and the digestible and metabolizable energy content of high-oil corn varieties and its effects on growth performance of pigs. Arch Anim Nutr. 2003;57:297-306. https://doi.org/10.1080/0003942031 0001594432

21. AOAC [Association of Official Analytical Chemists]. Official methods analysis. 15th ed. Arlington, VA: Association of Official Analytical Chemists; 1990.

22. Lammers PJ, Kerr BJ, Weber TE, Dozier III WA, Kidd MT, Bregendahl K, et al. Digestible and metabolizable energy of crude glycerol for growing pigs. J Anim Sci. 2008;86:602-8. https://doi.org/10.2527/jas.2007-0453

23. Noblet J, Perez JM. Prediction of digestibility of nutrients and energy values of pig diets from chemical analysis. J Anim Sci. 1993;71:3389-98. https://doi.org/10.2527/1993.71123389x

24. Pfeiffer A, Henkel H, Verstegen MWA, Philipczyk I. The influence of protein intake on water balance, flow rate and apparent digestibility of nutrients at the distal ileum in growing pigs. Livest Prod Sci. 1995;44:179-87. https://doi.org/10.1016/0301-6226(95)00070-4

25. O'Connell JM, Callan JJ, O'Doherty JV. The effect of dietary crude protein level, cereal type and exogenous enzyme supplementation on nutrient digestibility, nitrogen excretion, faecal volatile fatty acid concentration and ammonia emissions from pigs. Anim Feed Sci Technol. 2006;127:73-88. https://doi.org/10.1016/j.anifeedsci.2005.09.002

26. Kong C, Park CS, Kim BG. Effects of an enzyme complex on in vitro dry matter digestibility of feed ingredients for pigs. Springerplus. 2015;4:261. https://doi.org/10.1186/s40064-0151060-1

27. Wang D, Piao XS, Zeng ZK, Lu T, Zhang Q Li PF, et al. Effects of keratinase on performance, nutrient utilization, intestinal morphology, intestinal ecology and inflammatory response of weaned piglets fed diets with different levels of crude protein. Asian Australas J Anim Sci. 2011;24:1718-28. https://doi.org/10.5713/ajas.2011.11132

28. O'Shea CJ, Mc Alpine PO, Solan P, Curran T, Varley PF, Walsh AM, et al. The effect of protease and xylanase enzymes on growth performance, nutrient digestibility, and manure odour in grower-finisher pigs. Anim Feed Sci Technol. 2014;189:88-97. https://doi.org/10.1016/j.anifeedsci.2013.11.012

29. Dourmad JY, Henry Y. Effect of feeding and performance on nitrogen excretion in pigs. Inra Prod Anim. 1994;7:263-74. https://doi.org/10.20870/productions-animales.1994.7.4.4174

30. Canh TT, Aarnink AJA, Schutte JB, Sutton A, Langhout DJ, Verstegen MWA. Dietary protein affects nitrogen excretion and ammonia emission from slurry of growing-finishing pigs. Livest Prod Sci. 1998;56:181-91. https://doi.org/10.1016/S0301-6226(98)00156-0

31. Lee P, Kay RM, Cullen A, Fullarton P, Jagger S. Dietary manipulation to reduce nitrogen excretion by pigs and its effect on performance. EAAP Publ. 1993;69:163-8.

32. Liu SY, Selle PH, Cowieson AJ. Strategies to enhance the performance of pigs and poultry on sorghum-based diets. Anim Feed Sci Technol. 2013;181:1-14. https://doi.org/10.1016/j.anifeedsci.2013.01.008

33. Chen H, Zhang S, Park I, Kim SW. Impacts of energy feeds and supplemental protease on growth performance, nutrient digestibility, and gut health of pigs from 18 to $45 \mathrm{~kg}$ body weight. 
Anim Nutr. 2017;3:359-65. https://doi.org/10.1016/j.aninu.2017.09.005

34. Wang D, Zeng Z, Piao X, Li P, Xue L, Zhang Q, et al. Effects of keratinase supplementation of corn-soybean meal-based diets on apparent ileal amino acid digestibility in growing pigs and serum amino acids, cytokines, immunoglobulin levels and loin muscle area in nursery pigs. Arch Anim Nutr. 2011;65:290-302. https://doi.org/10.1080/1745039X.2011.586140

35. Hou DH, Chang SKC. Structural characteristics of purified glycinin from soybeans stored under various conditions. J Agric Food Chem. 2004;52:3792-800. https://doi.org/10.1021/ jf035072z 